\title{
PENGARUH NEGARA ASAL, CITRA MEREK DAN PERSEPSI KUALITAS TERHADAP MINAT BELI SEPEDA MOTOR YAMAHA VIXION DI KOTA YOGYAKARTA
}

\author{
Nandia Anggraini \\ nandiaanggraini85@gmail.com \\ Universitas Ahmad Dahlan \\ Fitroh Adhilla \\ fitauad@yahoo.com \\ Universitas Ahmad Dahlan
}

\begin{abstract}
ABSTRAK
This study was conducted to determine the effect of country of origin, brand image, and perceived quality of purchase interest in Yamaha V-Ixion motorbikes in Yogyakarta City, samples taken were 100 respondents using non-probability sampling methods with purposive sampling technique. Data collection techniques using a questionnaire that has been tested for validity and reliability. The data analysis technique used to answer the hypothesis is multiple regression analysis. The results of this study indicate that: (1) There is no significant influence between the country of origin variables on buying interest; (2) There is a significant influence between brand image variables on buying interest; (3) There is a significant influence between perceived quality variables on buying interest; and (4) country of origin, brand image, and perceived quality simultaneously influence buying interest.
\end{abstract}

Keywords: Country of Origin; Brand Image; Quality Perception; Purchase Interest.

\section{PENDAHULUAN}

Perkembangan ekonomi dewasa ini mengarah pada persaingan ketat. Perusahaan ditutntut untuk memiliki suatu keunikan tersendiri yang dapat memikat konsumen dalam mempertahankan atau merebut pangsa pasar yang ada. Konsumen saat ini sangatlah kritis dalam memilih suatu produk sampai pada keputusan untuk membeli produk tersebut. Tawaran produk saat ini sangatlah beragam dan banyak tak terkecuali untuk sepeda motor dengan berbagai merek, model, tipe, warna dan spesifikasi lainnya. Pilihan yang semakin banyak ini membuat konsumen dapat menentukan pilihannya akan suatu produk yang dapat memikat dan membuat konsumen tersebut membeli serta loyal terhadap produk tersebut.

Sebelum menentukan produk apa yang akan dibeli untuk sebagian konsumen akan melihat dari mana asal produk tersebut diproduksi. Negara asal secara umum dianggap menjadi karakteristik suatu produk. Negara asal suatu produk akan menimbulkan persepsi kualitas akan baik buruknya suatu produk. Peran negara asal sangatlah penting dalam mempengaruhi dan mengevaluasi suatu produk (Chu et al., 2008). Salah satu aspek yang sering kali dijadikan acuan adalah melihat citra merek suatu produk. Citra merek merupakan seperangkat keyakinan, ide, kesan yang dimiliki seseorang terhadap suatu merek (Simamora, 2004). Apabila para konsumen beranggapan bahwa merek tertentu secara fisik berbeda dari merek pesaing citra merek tersebut akan melekat secara terus-menerus sehingga dapat menciptakan loyalitas konsumen (Rangkuti, 2004).

Keputusan untuk membeli suatu produk juga dipengaruhi oleh persepsi kualitas. Persepsi kualitas merupakan 
penilaian konsumen terhadap kualitas produk secara keseluruhan berkenaan dengan karakteristik produk yang diharapkan (Ambrawati, 2006). Semakin tinggi nilai yang diperoleh oleh konsumen maka minat beli produk tersebut juga semakin tinggi. Persepsi kualitas dipengaruhi oleh dua dimensi, yaitu dalam bentuk kualitas produk dan kualitas jasa (Lindawati, 2005).

Dengan adanya merek dan persepsi kualitas yang baik menjadi dasar untuk mempengaruhi minat beli konsumen. Konsumen sering kali membentuk preferensi terhadap salah satu merek atau perusahaan karena image-nya. Minat beli merupakan suatu tahap penting yang harus diperhatikan oleh para pemasar. Hal ini dikarenakan suatu kondisi yang mendahului sebelum individu mempertimbangkan atau membuat keputusan dalam memilih sebuah produk atau jasa.

Salah satu industri yang tumbuh pesat saat ini adalah otomotif. Perkembangannya ditunjang dengan bertambah luasanya sarana jalan dan pendapatan masyarakat yang meningkat menempatkan sepeda motor bukan lagi untuk golongan menengah keatas. Sepeda motor merupakan transportasi yang paling banyak dimiliki oleh masyarakat. Jepang merupakan negara yang memproduksi sepeda motor dan berhasil menguasai pangsa pasar di Indonesia. Salah satu sepeda motor yang diproduksi oleh Jepang adalah Yamaha V-ixion. Yamaha V-ixion mampu menarik minat beli konsumen karena kecanggihan teknologi yang digunakan, inovatif, lincah, dan penggunaan bahan bakar yang irit serta layanan purna jual yang baik.

Tujuan dari penelitian ini di antaranya: 1) untuk mengetahui pengaruh negara asal terhadap minat beli sepeda motor Yamaha V-ixion di Kota Yogyakarta, 2) untuk mengetahui pengaruh citra merek terhadap minat beli sepeda motor Yamaha V-ixion di Kota Yogyakarta, 3) untuk mengetahui pengaruh persepsi kualitas terhadap minat beli sepeda motor Yamaha V-ixion di Kota Yogyakarta dan 4) untuk mengetahui pengaruh negara asal, citra mereka, dan persepsi kualitas terhadap minat beli sepeda motor Yamaha V-ixion di Kota Yogyakarta.

\section{REVIEW LITERATUR DAN HIPOTESIS}

\section{Landasan Teori}

\section{Negara Asal}

Bisnis global sekarang memberikan kesulitan bagi konsumen untuk mengidentifikasi secara tepat asal suatu produk. Banyak penelitian telah dilakukan untuk melihat reaksi konsumen terhadap produk buatan luar negeri. Globalisasi telah membawa produk yang dibuat di suatu negara tapi membawa nama merek asing. Banyak produk yang dibuat di suatu negara namun ditampilkan dengan merek yang sama. Maka label made in menjadi sifat (atribut) yang penting bagi konsumen dalam proses penilaian produk. Hal ini menunjukkan bahwa negara asal produk mempunyai pesan yang sangat penting dalam kegiatan pemasaran internasional. Selain itu bagi perusahaan sendiri, hal itu sangat penting mendapat perhatian terutama terdapatnya perbedaan sikap dari konsumen dalam menilai berbagai negara itu untuk mengembangkan praktek pemasaran yang efektif.

\section{Citra Merek}

Citra merek merupakan interprestasi dari target market terhadap atribut produk, manfaat, kegunaan, dan karakteristik produk. Dengan kata lain, brand image meliputi segala sesuatu yang dipikirkan dan dirasakan oleh konsumen ketika mendengar atau melihat merek tersebut (Hawkins, 2014). 
3. Persepsi Kualitas

Menurut Aaker dalam Broto (2002) menegaskan suatu hal yang harus selalu diingat, yaitu bahwa persepsi kualitas merupakan persepsi pada pelanggan, oleh sebab itu persepsi pelanggan akan melibatkan apa yang penting bagi pelanggan karena setiap pelanggan memiliki kepentingan (yang diukur secara relatif) yang berbeda beda terhadap suatu produk atau jasa. Maka dapat dikatakan bahwa membahas persepsi kualitas berarti akan membahas keterlibatan dan kepentingan pelanggan.

\section{Minat Beli}

Kotler (2009) menyatakan bahwa minat beli konsumen merupakan sebuah perilaku konsumen dimana konsumen mempunyai keinginan dalam memilih, menggunakan, dan mengkonsumsi atau bahkan menginginkan suatu produk yang ditawarkan.

\section{Penelitian Terdahulu}

1. Yanthi (2015). Penelitian ini dilakukan untuk mengetahui pengaruh country of origin, brand image, dan perceived quality terhadap minat beli sepeda motor Honda Beat di Kota Denpasar. Penelitian ini dilakukan di Kota Denpasar, sampel yang diambil sebanyak 152 orang dengan metode purposive sampling. Pengumpulan data dilakukan dengan penyebaran kuesioner dengan menggunakan skala Likert 5 poin untuk mengukur 19 indikator. Teknik analisis yang digunakan adalah regresi linear berganda. Hasil penelitian ini menunjukan bahwa variabel country of origin berpengaruh positif dan signifikan terhadap minat beli sepeda motor Honda Beat di Kota Denpasar, variabel brand image berpengaruh positif dan signifikan terhadap minat beli sepeda motor Honda Beat di Kota Denpasar, variabel perceived quality berpengaruh positif dan signifikan terhadap minat beli sepeda motor
Honda Beat di Kota Denpasar.Hal ini menunjukkan bahwa country of origin, brand image, dan perceived quality dapat meningkatkan minat beli sepeda motor Honda Beat di Kota Denpasar.

2. Larasati (2015). Penelitian ini bertujuan untuk mengetahui seberapa besar pengaruh citra merek sepeda motor Honda terhadap minat beli konsumen di Yogyakarta. Jenis dan sumber data yang digunakan dalam penelitian ini adalah jenis data kuantitatif dan sumber data primer dengan menyebarkan kuesioner secara langsung kepada 70 responden di Yogyakarta. Teknik pengambilan sampel yang digunakan adalah teknik non probability sampling dengan cara convenience. Untuk metode analisis digunakan metode analisis regresi linier sederhana. Hasil dari penelitian ini menunjukkan bahwa variabel citra merek yang terdiri dari keunggulan asosiasi merek, kekuatan asosiasi merek, dan keunikan asosiasi merek dari sepeda motor Honda memiliki pengaruh yang signifikan terhadap minat beli konsumen di Yogyakarta ditunjukkan dengan nilai signifikansi sebesar 0,000 kurang dari sama dengan 0,05 yang berarti $\mathrm{H}_{0}$ ditolak dan $\mathrm{H}_{\mathrm{a}}$ diterima. Citra merek mempengaruhi minat beli konsumen sebesar 50,3\%, sedangkan sisanya yaitu sebesar $49,7 \%$ dipengaruhi oleh faktor lain.

\section{Hipotesis}

H1: Ada pengaruh signifikan negara asal terhadap minat beli sepeda motor Yamaha V-ixion di Kota Yogyakarta.

H2: Ada pengaruh signifikan citra merek terhadap minat beli sepeda motor Yamaha V-ixion di Kota Yogyakarta.

H3: Ada pengaruh signifikan persepsi kualitas terhadap minat beli sepeda 
motor Yamaha V-ixion di Kota Yogyakarta.

H4: Ada pengaruh signifikan negara asal, citra merek, dan persepsi kualitas terhadap minat beli sepeda motor Yamaha V-ixion di Kota Yogyakarta.

\section{METODE PENELITIAN}

\section{Populasi dan Sampel}

Populasi adalah wilayah generalisasi yang terdiri atas objek atau subjek yang mempunyai kualitas dan karakteristik tertentu yang ditetapkan oleh peneliti atau dipelajari dan kemudian ditarik kesimpulannya (Sugiyono, 2014). Populasi dalam penelitian ini adalah masyarakat di daerah Kota Yogyakarta yang belum memiliki sepeda motor Yamaha V-ixion dan akan membeli sepeda motor Yamaha V-ixion di Kota Yogyakarta.

Sampel adalah bagian dari jumlah dan karakteristik yang dimiliki oleh populasi. Apabila populasi besar, peneliti tidak mungkin mempelajari semua yang ada pada populasi, misalnya karena keterbatasan dana, tenaga, dan waktu, sehingga peneliti dapat menggunakan sampel yang diambil dari populasi itu dan sampel yang diambil dari populasi harus betul-betul mewakili (Sugiyono, 2014). Dalam penelitian ini sampel yang digunakan sebanyak 100 responden.

\section{Definisi Operasional}

1. Variabel Independen

a. Negara Asal

Menurut Abdi (2009) negara asal merupakan gambaran reputasi stereotype konsumen dan pelaku bisnis lainnya terhadap suatu barang yang diakaitkan dengan suatu negara tertentu. Gambaran tersebut dapat berasal dari typical produk itu sendiri (representative product), karakteristik negara asal (economic and political background), sejarah (history) dan kebiasaan atau tradisi dari negara asal (tradition). Indikator yang digunakan untuk menilai variabel negara asal di antaranya inovasi, kemampuan teknologi, selera desain, kualitas, reputasi dan citra negara.

b. Citra Merek

Citra merek merupakan interprestasi dari target market terhadap atribut produk, manfaat, kegunaan, dan karakteristik produk. Dengan kata lain, brand image meliputi segala sesuatu yang dipikirkan dan dirasakan oleh konsumen ketika mendengar atau melihat merek tersebut (Hawkins, 2014). Indikator yang digunakan untuk menilai variabel citra merek di antaranya lambang, merek dan citra pengguna.

c. Persepsi Kualitas

Persepsi kualitas menurut Aaker (2008) dapat didefinisikan sebagai persepsi pelanggan terhadap keseluruhan kualitas atau keunggulan suatu produk atau jasa layanan berkaitan dengan apa yang diharapkan oleh pelanggan. Indikator yang digunakan untuk menilai variabel persepsi kualitas di antaranya tampilan, daya tahan, kesesuaian spesifikasi, fitur dan tingkat keandalan.

\section{Variabel Dependen}

Variabel dependen yang digunakan dalam penelitian ini adalah minat beli. Kotler (2009) menyatakan bahwa minat beli konsumen merupakan sebuah perilaku konsumen dimana konsumen mempunyai keinginan dalam memilih, menggunakan, dan mengkonsumsi atau bahkan menginginkan suatu produk yang ditawarkan. Indikator yang digunakan untuk menilai variabel minat beli di antaranya pencarian informasi, pertimbangan untuk mencoba, ketertarikan untuk mencoba, 
keingintauan mengenai fitur dan ketertarikan untuk memiliki

\section{Uji Instrumen}

1. Uji Validitas

Validitas suatu alat ukur adalah apakah suatu alat ukur dapat mengukur apa yang sebenarnya ingin diukur. Uji validitas perlu dilakukan untuk mengetahui sejauh mana suatu alat ukur yang digunakan dalam penelitian dapat mengukur apa yang sebenarnya ingin peneliti ukur atau dapat digunakan untuk menguji instrumen penelitian agar instrumen tersebut dapat memberikan hasil sesuai dengan tujuannya (Cooper, 2001).

Pengujian validitas yang dilakukan adalah construct validity dengan metode confirmatory factor analysis yang dilakukan dengan bantuan program SPSS. Analisis faktor digunakan dalam analisis penelitian ini karena merupakan salah satu metode statistik multivariate yang tujuan utamanya untuk meringkas atau mengurangi data atau variabel yang akan diperlukan untuk dianalisis. Analisis faktor memecahkan masalah yang menyangkut hubungan timbal balik antara sejumlah indikator dan kemudian menjelaskan keterkaitan antar indikator ke dalam dimensi-dimensi yang mendasari hubungan tersebut. Dan karena item-item pertanyaan dalam kuisioner diadopsi dari penelitian sebelumnya dengan dimodifikasi maka analisis faktor yang dilakukan bersifat confirmatory, yaitu saat pengolahan pada tahap extraction dipilih number of factor adalah 4 sesuai dengan variabel yang diuji dalam model penelitian. Kriteria signifikansi terhadap item-item pertanyaan dalam penelitian ini didasarkan pada signifikansi praktis (practical significance) (Hair et al., 1998) seperti terlihat pada tabel berikut:

\begin{tabular}{|ll|l|}
\hline \multicolumn{2}{|l|}{ Faktor Loading } & Keterangan \\
\hline Lebih besar dari & Level minimal \\
\hline Lebih & besar dari & Sangat Penting \\
0.40 & & \\
\hline Lebih & besar dari & Signifikan \\
0.50 & & \\
\hline
\end{tabular}

Pedoman umum yang dipakai adalah semakin besar factor loading semakin penting indikator tersebut dalam menafsirkan suatu faktor (Hair $e t$ al., 1998). Item-item yang mempunyai factor loading kurang dari 0,40 akan dikeluarkan karena dianggap hanya mempunyai kemampuan menafsirkan suatu faktor pada level minimum. Sedangkan item yang mempunyai factor loading lebih besar dari 0,40 dianggap signifikan dan bisa dimasukkan sebagai anggota suatu faktor.

Dari hasil reliabilitas, dilakukan analisis faktor terhadap item-item yang telah memenuhi nilai reliabilitas dengan memasukkan semua item tersebut dan kemudian mengeliminasi item tersebut satu per satu bagi item yang tidak memenuhi persyaratan seperti dijelaskan sebelumnya, yaitu memiliki lebih dari satu nilai loadings yang mirip pada beberapa faktor yang berbeda, memiliki nilai loading yang lebih besar pada faktor lain dibandingkan pada faktornya, atau tidak memiliki nilai loading pada faktornya. 
2. Uji Reliabilitas

Uji reliabilitas untuk menguji ketepatan instrumen pengukur dengan konsistensi diantara butir-butir pernyataan dalam suatu instrumen. Reliabilitas berkaitan dengan ketepatan prosedur pengukuran dan konsistensi. Suatu alat ukur yang dinilai reliabel jika pengukur tersebut menunjukkan hasil-hasil yang konsisten dari waktu ke waktu.

Peneliti menguji instrumen penelitian dengan sampel sejumlah 30 responden. Koefisien reliabilitas ditunjukkan oleh koefisien Cronbach Alpha yang berkisar antara 0 sampai 1 . Semakin tinggi nilai koefisien Cronbach Alpha berarti semakin tinggi reliabilitas alat ukur yang digunakan. Untuk menguji reliabilitas dalam penelitian ini adalah dengan membandingkan Cronbach Coefficient Alpha (r Alpha) pada hasil olahan SPSS dengan Rule of Thumb/Kesepakatan Umum dari koefisien alfa yaitu lebih besar dari 0,6 untuk penelitian eksploratori.

\section{Teknik Analisis Data}

\section{Analisis Regresi Berganda}

Analisis regresi pada dasarnya dilakukan untuk mengetahui kekuatan hubungan antara dua variabel atau lebih (Ghozali, 2013). Teknik regresi cukup fleksibel untuk menguji hubungan antar variabel yang bersifat dependen dan memiliki beberapa variance atau jenis sehingga dapat diperoleh model yang paling sesuai dengan situasi yang dihadapi.

Dalam analisis regresi, selain mengukur tingkat hubungan antara dua variabel atau lebih, juga menunjukkan arah suatu hubungan antara variabel dependen dengan variabel independen. Variabel dependen diasumsikan random/stokastik yang berarti memiliki distribusi probalistik (Ghozali, 2013). Hubungan antara variabel dependen (Y) dan variabel independen (X) dapat digambarkan dengan persamaan sebagai berikut:

$Y=a+b_{1} X_{1}+b_{2} X_{2}+b_{3} X_{3}$

Dimana :

$\mathrm{Y}=$ Variabel Dependen (Minat beli)

$\mathrm{X}_{1}=$ Negara asal

$\mathrm{X}_{2}=$ Citra Merek

$\mathrm{X}_{3}=$ Persepsi Kualitas

a $=$ Konstanta

$\mathrm{b} \quad=$ Koefisien Regresi

\section{Uji Hipotesis}

1. Uji Parsial (Uji T)

Uji $\mathrm{t}$ digunakan untuk menguji signifikansi hubungan antara variabel $\mathrm{X}$ dan $\mathrm{Y}$, apakah variabel $\mathrm{X}_{1}, \mathrm{X}_{2}$, dan $\mathrm{X}_{3}$ (negara asal, citra merek, dan persepsi kualitas) benar-benar berpengaruh terhadap variabel Y (minat beli) secara terpisah atau parsial (Ghozali, 2005). Hipotesis yang digunakan dalam pengujian ini adalah :

$\mathrm{H}_{0}$ : Negara asal, citra merek, dan persepsi kualitas tidak mempunyai pengaruh yang signifikan secara terhadap minat beli konsumen.

$\mathrm{H}_{\mathrm{a}}$ : Negara asal, citra merek, dan persepsi kualitas mempunyai pengaruh yang signifikan terhadap minat beli konsumen.

Dasar pengambilan keputusan (Ghozali, 2005) adalah dengan menggunakan angka probabilitas signifikansi, yaitu :
a. Apabila angka probabilitas signifikansi $>0.05$, maka $\mathrm{H}_{0}$ diterima dan $\mathrm{H}_{\mathrm{a}}$ ditolak.
b. Apabila angka probabilitas signifikansi $<0.05$, maka $\mathrm{H}_{0}$ ditolak dan $\mathrm{H}_{\mathrm{a}}$ diterima.

\section{Uji Simultan (Uji F)}

Dalam penelitian ini, uji $\mathrm{F}$ digunakan untuk mengetahui tingkat siginifikansi pengaruh variabel-variabel independen secara bersama-sama (simultan) terhadap variabel dependen (Ghozali, 2005). Dalam penelitian ini, hipotesis yang digunakan adalah : 
$\mathrm{H}_{0}$ : Negara asal, citra merek, dan persepsi kualitas tidak mempunyai pengaruh signifikan secara bersamasama terhadap minat beli konsumen.

$\mathrm{H}_{\mathrm{a}}$ : Negara asal, citra merek, dan persepsi kualitas mempunyai pengaruh yang signifikan secara bersama-sama terhadap minat beli konsumen.

Dasar pengambilan keputusannya (Ghozali, 2005) adalah dengan menggunakan angka probabilitas signifikansi, yaitu:

a. Apabila probabilitas signifikansi > 0.05, maka $\mathrm{H}_{0}$ diterima dan $\mathrm{H}_{\mathrm{a}}$ ditolak.

b. Apabila probabilitas signifikansi < 0.05, maka $\mathrm{H}_{0}$ ditolak dan $\mathrm{H}_{\mathrm{a}}$ diterima.

3. Uji Koefisien Determinasi

Koefisien determinasi $\left(\mathrm{R}^{2}\right)$ dimaksudkan untuk mengetahui tingkat ketepatan paling baik dalam analisa regresi dimana hal yang ditunjukan oleh besarnya koefisien determinasi $\left(\mathrm{R}^{2}\right)$ antara 0 (nol) dan I (satu). Koefsien determinasi $\left(\mathrm{R}^{2}\right)$ nol variabel independen sama sekali tidak berpengaruh terhadap variabel dependen. Apabila koefisien determinasi semakin mendekati satu, maka dapat dikatakan bahwa variabel independen berpengaruh terhadap variabel dependen, Selain itu koefisien determinasi $\left(\mathrm{R}^{2}\right)$ dipergunakan untuk mengetahui prosentase perubahan variabel tidak bebas (Y) yang disebabkan oleh variabel bebas (X).

\section{HASIL PENELITIAN DAN PEMBAHASAN}

\section{Hasil Analisis Responden}

Data Responden Berdasarkan Usia

\begin{tabular}{|c|c|c|}
\hline Kelompok Usia & Frekuensi & Prosentase \\
\hline Antara 17-21 Tahun & 33 & $33 \%$ \\
\hline Antara 22-27 Tahun & 39 & $39 \%$ \\
\hline Antara 28-32 Tahun & 11 & $11 \%$ \\
\hline Antara 33-38 Tahun & 9 & $9 \%$ \\
\hline Diatas 38 tahun & 8 & $8 \%$ \\
\hline Total & 100 & $100 \%$ \\
\hline
\end{tabular}

Dari tabel di atas, dapat dilihat bahwa usia responden terbanyak adalah mereka yang berusia antara $22-27$ tahun yaitu sebanyak 39 responden (39\%), kemudian antara 17- 21 tahun sebanyak 33 responden (33\%), antara 28 - 32 tahun yaitu sebanyak 11 responden (11\%), antara 33 - 38 tahun yaitu sebanyak 9 responden (9\%), dan diatas 38 tahun sebanyak 8 responden $(8 \%)$. Data ini menunjukkan bahwa mayoritas responden adalah yang berada pada usia antara $22-27$ tahun.

Data Responden Berdasarkan Pembagian Wilayah

\begin{tabular}{|c|c|c|}
\hline Bagian Wilayah & Frekuensi & Prosentase \\
\hline Kecamatan Mantrijeron & 4 & $4 \%$ \\
\hline Kecamatan Kraton & 3 & $3 \%$ \\
\hline Kecamatan Mergangsan & 8 & $8 \%$ \\
\hline Kecamatan Umbulharjo & 13 & $13 \%$ \\
\hline Kecamatan Kotagede & 29 & $29 \%$ \\
\hline Kecamatan Gondokusuman & 11 & $4 \%$ \\
\hline Kecamatan Danurejan & 4 & $9 \%$ \\
\hline Kecamatan Pakualaman & 9 & $3 \%$ \\
\hline Kecamatan Gondomanan & 3 & $2 \%$ \\
\hline Kecamatan Ngampilan & 2 & $5 \%$ \\
\hline Kecamatan Wirobrajan & 5 & $1 \%$ \\
\hline Kecamatan Gedongtengen & 1 & $1 \%$ \\
\hline Kecamatan Jetis & 7 & $\mathbf{1 0 0} \%$ \\
\hline Kecamatan Tegalrejo & 1 & 100 \\
\hline Total & & \\
\hline
\end{tabular}

Dari tabel di atas, dapat dilihat bahwa responden terbanyak berasal dari Kecamatan Kotagede yaitu sebanyak 29 responden (29\%). Kemudian Kecamatan 
Umbulharjo dengan 13 responden (13\%), Kecamatan Gondokusuman sebanyak 11 responden (11\%), Kecamatan Pakualaman sebanyak 9 responden (9\%), Kecamatan Mergangsang sebanyak 8 responden (8\%), Kecamatan Jetis sebanyak 7 responden (7\%), Kecamatan Wirobrajan sebanyak 5 responden $(5 \%)$, Kecamatan Danurejan dan Mantrijeron dengan masing - masing Kecamatan didapatkan responden sebanyak 4 responden (4\%), pada Kecamatan Kraton dan Kecamatan Gondomanan didapatkan 3 responden (3\%), Kecamatan Ngampilan sebanyak 2 responden (2\%), serta responden yang paling sedikit didapatkan dari Kecamatan Gedongtengen dan Kecamatan Tegalrejo yaitu sebanyak 1 responden (1\%) di masing - masing kecamatan. Sehingga dapat disimpulkan bahwa responden terbanyak berasal dari Kecamatan Kotagede serta responden paling sedikit berasal dari Kecamatan Gedongtengen dan Kecamatan Tegalrejo.

\section{Hasil Penelitian}

1. Hasil Uji Validitas

\section{Hasil Uji Validitas}

\begin{tabular}{|c|c|c|c|c|c|c|}
\hline \multirow{2}{*}{ Indikator } & \multirow{2}{*}{ Pertanyaan } & \multicolumn{4}{|c|}{ Komponen faktor } & \multirow{2}{*}{ Status } \\
\hline & & 1 & 2 & 3 & 4 & \\
\hline \multirow{5}{*}{$\begin{array}{l}\text { Negara } \\
\text { Asal (X1) }\end{array}$} & $\mathrm{X} 1.2$ & 0,553 & & & & Valid \\
\hline & $\mathrm{X} 1.3$ & 0,761 & & & & Valid \\
\hline & $\mathrm{X} 1.4$ & 0,686 & & & & Valid \\
\hline & $\mathrm{X} 1.5$ & 0,731 & & & & Valid \\
\hline & $\mathrm{X} 1.6$ & 0,545 & & & & Valid \\
\hline \multirow{3}{*}{$\begin{array}{l}\text { Citra } \\
\text { Merek } \\
(\mathrm{X} 2) \\
\end{array}$} & $\mathrm{X} 2.1$ & & 0,863 & & & Valid \\
\hline & $\mathrm{X} 2.2$ & & 0,796 & & & Valid \\
\hline & $\mathrm{X} 2.3$ & & 0,690 & & & Valid \\
\hline \multirow{5}{*}{$\begin{array}{l}\text { Persepsi } \\
\text { Kualitas } \\
\text { (X3) }\end{array}$} & $\mathrm{X} 3.1$ & & & 0,731 & & Valid \\
\hline & $\mathrm{X} 3.2$ & & & 0,773 & & Valid \\
\hline & $\mathrm{X} 3.3$ & & & 0,811 & & Valid \\
\hline & $\mathrm{X} 3.4$ & & & 0,685 & & Valid \\
\hline & $\mathrm{X} 3.5$ & & & 0,528 & & Valid \\
\hline \multirow{4}{*}{$\begin{array}{l}\text { Minat } \\
\text { Beli }(\mathrm{Y})\end{array}$} & Y1 & & & & 0,804 & Valid \\
\hline & $\mathrm{Y} 2$ & & & & 0,665 & Valid \\
\hline & $\mathrm{Y} 4$ & & & & 0,775 & Valid \\
\hline & Y5 & & & & 0,647 & Valid \\
\hline
\end{tabular}

Dari tabel di atas dapat diketahui dalam pengujian validitas dan reliabilitas instrumen penelitian menggunakan tryout terhadap 30 responden. Dalam perhitungan, peneliti menggunakan bantuan komputer program SPSS versi 20.0.

a. Uji Validitas Variabel Negara Asal $\left(\mathrm{X}_{1}\right)$

Tabel component matrix pada hasil output SPSS terlihat bahwa terbentuk 2 component, yang artinya indikator X1.1, X1.2, X1.3, X1.4, $\mathrm{X} 1.5, \mathrm{X} 1.6$ mempunyai 6 item pertanyaan dimana item X1.1 memiliki nilai anti image yang terendah maka item X1.1 dihilangkan. Sehingga terbentuk 1 component, dimana tersisa 5 pertanyaan, indikator X1.2, X1.3, $\mathrm{X} 1.4, \mathrm{X} 1.5, \mathrm{X} 1.6$ tersebut dapat dinyatakan valid dan hanya menjelaskan faktor variabel negara asal.

b. Uji Validitas Variabel Citra Merek $\left(\mathrm{X}_{2}\right)$

Tabel component matrix pada hasil data output SPSS terbentuk 1 component yang artinya indikator $\mathrm{X} 2.1, \mathrm{X} 2.2$, X2.3 mempunyai 3 item pertanyaan dimana seluruh item pertanyaan tersebut dapat dinyatakan valid dan hanya menjelaskan faktor variabel citra merek.

c. Uji Validitas Persepsi Kualitas $\left(\mathrm{X}_{3}\right)$

Tabel component matrix pada hasil data output SPSS terbentuk 1 component yang artinya indikator X3.1, X3.2, X3.3, X3.4, X3.5 mempunyai 5 item pertanyaan dimana seluruh item pertanyaan tersebut dapat dinyatakan valid dan hanya menjelaskan faktor variabel persepsi kualitas.

d. Uji Validitas Minat Beli (Y)

Tabel component matrix pada hasil output SPSS terlihat bahwa terbentuk 2 component, yang artinya indikator Y1, Y2, Y3, Y4, Y5 mempunyai 6 item pertanyaan dimana item Y3 nilainya kurang dari 0,5 maka item 4.3 dihilangkang. Sehingga terbentuk 1 component, dimana tersisa 5 pertanyaan, indikator Y1, Y2, Y4, Y5 tersebut dapat dinyatakan valid dan hanya menjelaskan faktor variabel minat beli. 
2. Hasil Uji Reliabilitas

Hasil Uji Reliabilitas

\begin{tabular}{|l|l|l|}
\hline \multicolumn{1}{|c|}{ Variabel } & \multicolumn{1}{c|}{ Cronbach Alpha } & \multicolumn{1}{c|}{ Keterangan } \\
\hline Negara asal & 0,674 & Reliabel \\
\hline Citra merek & 0,635 & Reliabel \\
\hline Persepsi kualitas & 0,735 & Reliabel \\
\hline Minat beli & 0,713 & Reliabel \\
\hline
\end{tabular}

Dari tabel di atas menunjukkan bahwa item pertanyaan dari variabel penelitian berstatus reliabel. Hal ini terlihat dari koefisien Cronbach alpha bernilai lebih besar dari 0,60 maka instrumen penelitian (Kuisioner) yang digunakan dalam penelitian dinyatakan reliabel. Dengan demikian instrumen penelitian tersebut dapat digunakan untuk meneliti data - data sama pada kondisi relatif sama, dengan probabilitas hasil penelitian yang dapat dipercaya.

3. Hasil Uji Regresi Linier Berganda Hasil Pengolahan Data Analisis Regresi Berganda

\begin{tabular}{|c|c|c|}
\hline \multirow[t]{2}{*}{ Model } & \multicolumn{2}{|c|}{ Unstandardized Coefficients } \\
\hline & B & Std. Error \\
\hline 1 (Constant) & 1,572 & .515 \\
\hline Negara_asal & .063 & .117 \\
\hline Citra_merek & .238 & .060 \\
\hline Persepsi_kualitas & .333 & .107 \\
\hline
\end{tabular}

Hasil dari pengolahan data maka dapat diketahui persamaan linear berganda yaitu :

$\mathrm{Y}=1.572+0.063 X_{1}+0.238 X_{2}+$ $0.333 X_{3}$

Dari persamaan garis linear regresi berganda diatas, dapat diartikan bahwa:

Y: Variabel yang nilainya akan diprediksi oleh variabel independen. Dalam penelitian ini yang menjadi variabel dependen adalah minat beli konsumen Motor Yamaha V-ixion di Kota Yogyakarta yang nilainya diprediksi oleh variabel negara asal, variabel citra merek, dan variabel persepsi kualitas.

a: 1.572 merupakan nilai konstanta, dengan demikian nilai konstanta ini menunjukkan besarnya nilai variabel minat beli motor Yamaha V-ixion di Kota Yogyakarta jika variabel independen sama dengan nol.

b1: 0.063 merupakan koefisien variabel negara asal $\left(\mathrm{X}_{1}\right)$ yang mempengaruhi minat beli Motor Yamaha V-ixion di Kota Yogyakarta (Y). koefisien regresi $\left(b_{1}\right)$ sebesar 0.063 dengan tanda positif. Berdasarkan hasil tersebut maka dapat disimpulkan bahwa apabila negara asal $\left(\mathrm{X}_{1}\right)$ berubah atau naik satu satuan maka minat beli konsumen Yamaha Vixion akan naik sebesar 0.063 dengan asumsi variabel independen lainnya mempunyai nilai sama dengan nol atau konstan. Berdasarkan hasil tersebut maka dapat disimpulkan bahwa apabila perusahaan lebih mengenalkan mengenai negara asal maka minat beli terhadap sepeda motor Yamaha V-ixion akan mengalami peningkatan.

$\mathrm{b}_{2}$ : 0.238 merupakan koefisien arah variabel citra merek $\left(\mathrm{X}_{2}\right)$ yang mempengaruhi minat beli motor Yamaha V-ixion di Kota Yogyakarta $(\mathrm{Y})$. koefisien regresi $\left(b_{2}\right)$ sebesar 0.238 dengan tanda positif. Berdasarkan hasil tersebut maka dapat disimpulkan bahwa apabila citra merek $\left(\mathrm{X}_{2}\right)$ berubah atau naik satu satuan maka minat beli motor Yamaha V-ixion di Kota Yogyakarta akan naik sebesar 0.238 dengan asumsi variabel independen lainnya mempunyai nilai sama dengan nol atau konstan. Berdasarkan hasil tersebut maka dapat disimpulkan bahwa apabila perusahaan lebih meningkatkan citra merek maka minat beli terhadap sepeda motor Yamaha V-ixion akan semakin tinggi. 
$\mathrm{b}_{3}: 0.333$ merupakan koefisien arah variabel persepsi kualitas $\left(\mathrm{X}_{3}\right)$ yang mempengaruhi minat beli motor Yamaha V-ixion di Kota Yogyakarta $(\mathrm{Y})$. koefisien regresi $\left(b_{3}\right)$ sebesar 0.333 dengan tanda positif. Berdasarkan hasil tersebut maka dapat disimpulkan bahwa apabila Persepsi Kualitas $\left(\mathrm{X}_{3}\right)$ berubah atau naik satu satuan maka minat beli motor Yamaha V-ixion di Kota Yogyakarta akan naik sebesar 0.333 dengan asumsi variabel independen lainnya mempunyai nilai sama dengan nol atau konstan. Berdasarkan hasil tersebut maka dapat disimpulkan bahwa apabila perusahaan lebih meningkatkan persepsi kualitas yang baik maka minat beli terhadap sepeda motor Yamaha V-ixion akan semakin tinggi.

\section{Hasil Uji Parsial (Uji T)}

Hasil Pengujian data Uji t

\begin{tabular}{|c|c|}
\hline Model & Sig. \\
\hline 1 (Constant) & .003 \\
\hline Negara asal & .591 \\
\hline Citra merek & .000 \\
\hline Persepsi kualitas & .002 \\
\hline
\end{tabular}

Berdasarkan hasil olah data diatas dapat disimpulkan sebagai berikut :

1. Untuk variabel negara asal $\left(\mathrm{X}_{1}\right)$, dari hasil olah data menggunakan SPSS 20 nilai sign > alpha $(0,591>0,05)$, jadi negara asal $\left(\mathrm{X}_{1}\right)$ tidak berpengaruh signifikan terhadap minat beli (Y). Maka dapat diambil kesimpulan $\mathrm{H}_{01}$ diterima dan $\mathrm{H}_{\mathrm{a}}$ ditolak yaitu tidak ada pengaruh signifikan negara asal terhadap minat beli sepeda motor Yamaha V-ixion di Kota Yogyakarta.

2. Untuk variabel citra merek $\left(X_{2}\right)$, dari hasil olah data menggunakan SPSS
20 nilai sign $<$ alpha $(0,000<0,05)$, jadi citra merek $\left(\mathrm{X}_{2}\right)$ berpengaruh signifikan terhadap minat beli $(\mathrm{Y})$. Maka dapat diambil kesimpulan $\mathrm{H}_{02}$ ditolak dan $\mathrm{H}_{\mathrm{a} 2}$ diterima yaitu ada pengaruh signifikan citra merek terhadap minat beli sepeda motor Yamaha V-ixion di Kota Yogyakarta.

3. Untuk variabel persepsi kualitas $\left(\mathrm{X}_{3}\right)$, dari hasil olah data menggunakan SPSS 20 nilai sign < alpha $(0,002<0,05)$, jadi persepsi kualitas $\left(\mathrm{X}_{3}\right)$ berpengaruh signifikan terhadap minat beli (Y). Maka dapat diambil kesimpulan $\mathrm{H}_{03}$ ditolak dan $\mathrm{H}_{\mathrm{a} 3}$ diterima yaitu ada pengaruh signifikan persepsi kualitas terhadap minat beli sepeda motor Yamaha Vixion di Kota Yogyakarta.

5. Hasil Uji Simultan (Uji F)

Hasil olah data Uji F

\begin{tabular}{|ll|c|}
\hline Model & Sig. \\
\hline 1 & Regression & \\
& Residual & \\
& Total & \\
& & \\
& & \\
\hline
\end{tabular}

Berdasarkan hasil olah data menggunakan SPSS 20 nilai sign < alpha $(0,000<0,05)$, jadi $\mathrm{H}_{\mathrm{a}}$ diterima dan $\mathrm{H}_{0}$ ditolak. Dengan demikian dapat disimpulkan bahwa ada pengaruh signifikan negara asal, citra merek, dan persepsi kualitas terhadap minat beli sepeda motor Yamaha V-ixion di Kota Yogyakarta.

6. Hasil Uji Koefisien Determinasi Hasil Perhitungan Koefisien Determinasi

\begin{tabular}{|l|r|}
\hline Model & R square \\
\hline 1 & .285 \\
\hline
\end{tabular}


Berdasarkan hasil olah data menggunakan SPSS 20 di dadapatkan nilai koefisien determinasi $\mathrm{R}^{2}$ sebesar 0,285 hal ini menunjukkan bahwa sebesar 28,5\% minat beli sepeda motor Yamaha V-ixion di Kota Yogyakarta dipengaruhi oleh variasi ketiga variabel yang digunakan yaitu negara asal, citra merek, dan persepsi kualitas. Sedangkan sisanya $71,5 \%$ dipengaruhi oleh variabel lainnya.

\section{Pembahasan}

Berdasarkan hasil uji $\mathrm{t}$ dan uji $\mathrm{F}$ dari ketiga variabel yang mempengaruhi minat beli yaitu negara asal, citra merek, dan persepsi kualitas sebagai berikut :

1. Pengaruh variabel negara asal terhadap minat beli sepeda motor Yamaha Vixion di Kota Yogyakarta tidak signifikan. Hal ini dikarenakan nilai sign > alpha $(0,591>0,05)$, jadi negara asal $\left(\mathrm{X}_{1}\right)$ tidak berpengaruh signifikan terhadap minat beli (Y). Maka dapat diambil kesimpulan $\mathrm{H}_{01}$ diterima dan $\mathrm{H}_{\mathrm{a} 1}$ ditolak yaitu tidak ada pengaruh signifikan negara asal terhadap minat beli sepeda motor Yamaha V-ixion di Kota Yogyakarta. Dengan demikian negara asal belum terlalu berpengaruh terhadap minat beli sepeda motor Yamaha V-ixion di Kota Yogyakarta, selain hal tersebut promosi yang dilakukan oleh perusahaan otomotif hanya mengenai spesifikasi motor tersebut dan tidak menyertakan dari mana negara asal motor tersebut di produksi sehingga masyarakat tidak terlalu mengerti atau mengenal dengan jelas mengenai negara asal.

2. Pengaruh citra merek terhadap minat beli sepeda motor Yamaha V-ixion di Kota Yogyakarta sangatlah signifikan. Hal ini dikarenakan nilai sign < alpha $(0,000<0,05)$, jadi citra merek $\left(\mathrm{X}_{2}\right)$ berpengaruh positif terhadap minat beli (Y). Maka dapat disimpulkan $\mathrm{H}_{02}$ ditolak dan $\mathrm{H}_{\mathrm{a} 2}$ diterima yaitu ada pengaruh signifikan citra merek terhadap minat beli Sepeda Motor Yamah V-ixion di Kota Yogyakarta. Dengan demikian citra merek mempengaruhi minat beli konsumen untuk membeli sepeda motor Yamaha $\mathrm{V}$-ixion. Hal ini menunjukkan bahwa citra merek sepeda motor Yamaha Vixion sudah baik di masyarakat.

3. Pengaruh persepsi kualitas terhadap minat beli sepeda motor Yamaha Vixion di Kota Yogyakarta sangatlah signifikan. Hal ini dikarenakan nilai sign $<$ alpha $(0,002<0,05)$, jadi persepsi kualitas $\left(\mathrm{X}_{3}\right)$ berpengaruh signifikan terhadap minat beli (Y). maka dapat disimpulkan Maka dapat disimpulkan $\mathrm{H}_{03}$ ditolak dan $\mathrm{H}_{23}$ diterima yaitu ada pengaruh signifikan persepsi kualitas terhadap minat beli Sepeda Motor Yamaha V-ixion di Kota Yogyakarta. Dengan demikian persepsi kualitas mempengaruhi minat beli konsumen untuk membeli sepeda motor Yamaha V-ixion. Hal ini menunjukkan bahwa persepsi masyarakat terhadap produk sepeda motor Yamaha V-ixion sudah baik.

4. Hasil Uji $F$ tiga variabel independen berpengaruh signifikan terhadap variabel dependen. Hal ini dikarenakan nilai sign $<$ alpha $(0.000<0.05)$, jadi Ha diterima dan H0 ditolak. Dengan demikian dapat disimpulkan bahwa ada pengaruh signifikan negara sasl, citra merek, dan persepsi kualitas terhadap minat beli sepeda motor Yamaha Vixion di Kota Yogyakarta. 


\section{KESIMPULAN DAN SARAN}

\section{Kesimpulan}

Berdasarkan hasil uji $\mathrm{T}$ dan uji $\mathrm{F}$ dari ketiga variabel yang mempengaruhi minat beli konsumen yaitu negara asal, citra merek, dan persepsi kualitas sebagai berikut:

1. Tidak terdapat pengaruh signifikan antara variabel negara asal $\left(\mathrm{X}_{1}\right)$ terhadap minat beli (Y) sepeda motor Yamaha V-ixion di Kota Yogyakarta.

2. Terdapat pengaruh signifikan antara variabel citra merek $\left(\mathrm{X}_{2}\right)$ terhadap minat beli (Y) sepeda motor Yamaha V-ixion di Kota Yogyakarta.

3. Terdapat pengaruh signifikan antara variabel persepsi kualitas $\left(\mathrm{X}_{3}\right)$ terhadap minat beli (Y) sepeda motor Yamaha V-ixion di Kota Yogyakarta.

4. Hasil uji $\mathrm{F}$ tiga variabel independent berpengaruh signifikan terhadap variabel dependent, dapat disimpulkan bahwa negara asal, citra merek, dan persepsi kualitas berpengaruh signifikan terhadap minat beli sepeda motor Yamaha V-ixion di Kota Yogyakarta.

\section{Saran}

Berdasarkan dari keterbatasan tersebut, maka penulis bermaksud untuk memberikan beberapa saran, antara lain :

1. Berdasarkan hasil analisa diketahui bahwa variabel- variabel dalam penelitian ini terdiri dari negara asal, citra merek, dan persepsi kualitas terhadap minat beli sepeda motor Yamaha V-ixion, Oleh karena itu perusahaan sepeda motor Yamaha Vixion lebih meningkatkan pengetahuan dan promosi mengenai negara asal dan meningkatkan citra merek serta persepsi kualitasnya, sehingga dari hal tersebut diharapkan ada peningkatan pada minat beli sepeda motor Yamaha V-ixion di Kota Yogyakarta.
2. Diharapkan pada penelitian selanjutnya untuk mengamati variabel negara asal, citra merek, dan persepsi kualitas atau menambahkan variabel - variabel lain. Demikian pula yang penulis harapkan pada penelitian-penelitian berikutnya, seiring berjalanya waktu lingkup penelitian saat ini yang terbatas pada lingkup wilayah kota Yogyakarta, kedepan dapat dikembangkan pada lingkup yang lebih luas lagi.

3. Diharapkan pada penelitian selanjutnya identitas responden lebih dilengkapi agar dapat mengungkap data pendapatan dan demografi lainnya.

\section{DAFTAR PUSTAKA}

Aaker, David A. (2008). Manajemen Ekuitas Merek: Memanfaatkan Nilai dari suatu Merek. Terjemahan oleh Aris Ananda. Cetakan Ketiga. Jakarta: Mitra Utama.

Abdi, Rianse. (2009). Metodologi Penelitian Sosial dan Ekonomi (Teori dan Aplikasi). Bandung: Alfabeta.

Ambrawati, Arie Tri Hertati. (2006). Hubungan Persepsi Kualitas Produk dengan Intensi Membeli Sepeda Motor Honda. Universitas Muhammadiyah malang.

Broto, Suharsono Adi. (2002). Analisis Pengaruh Persepsi Kualitas Terhadap Pemilihan Produk The Botol Sosro (Studi Kasus Di Kota Semarang). Tesis. Universitas Diponegoro Semarang.

Cooper, D.R. dan Schindler, P.S. (2001). Business Research Methods. USA: McGraw-Hill College.

Ghozali, Imam. (2005). Aplikasi Analisis Multivariate dengan program SPSS. 
Semarang: Badan Penerbit Universitas Diponegoro.

Ghozali, Imam. (2013). Aplikasi Analisis Multivariate dengan Program SPSS. Yogyakarta: Badan Penerbit BPFE.

Hair et al., (1998). Multivariate Data Analysis. Fifth Edition. River New Jersey: Prentice Hall, Upper Saddle.

Hawkins, D. I., \& Mothersbaught, D. L. (2014). Consumer Behavior: Building Marketing Strategy (12ed). New York: McGraw-Hill Education.

Kotler, Philip. (2009). Manajemen Pemasaran. Jakarta: Erlangga.

Larasati, Sekar Arum. (2015). Pengaruh Citra Merek Motor Honda Terhadap Minat Beli Konsumen Di Yogyakarta. Universitas Gajah Mada.

Lindawati. (2005). Analisis Kesadaran Merek, Persepsi Kualitas dan Asosiasi Merek Dalam Eksistensi Merek Pada Produk Merek "Lifeboy" di Surabaya. Jurnal Sains Pemasaran Indonesia. Vol. 4 No.1.

Rangkuti, Freddy. (2004). The Power Of Brand. Jakarta: PT. Gramedia Pustaka Utama.

Simamora, Bilson. (2004). Riset Pemasaran. Jakarta: Gramedia Utama.

Sugiyono. (2014). Metode Penelitian Kuantitatif, Kualitatif, dan Kombinasi (Mixed Methods). Bandung: Alfabeta.

Yanthi, Kadek Pratita dan I Made Jatra. (2015). Pengaruh Country Of Origin, Brand Image dan Perceived Quality terhadap minat beli Sepeda Motor Honda Beat di Kota Denpasar. E-
Jurnal Manajemen Universitas Udayana Bali. Vol.4, No.11, 2015: 3852 - 3881 . 